\title{
MISSING TRADER INTRA-COMMUNITY AND CAROUSEL VAT FRAUDS - ECJ AND ECtHR CASE LAW
}

\begin{abstract}
Jernej Podlipnik
Summary: This paper explains what missing trader intra-Community and carousel frauds are and how they are performed. A fault in taxing intra-Community supplies with value added tax (VAT) enables these frauds to take place. Member States and the European Commission are aware of the fault but are unable to agree on how to change the taxation of the mentioned supplies. Therefore, the fight against these frauds is conducted by improving tax inspection, tax cooperation between Member States, imposing liability on persons participating in the transactions in which these frauds occur, and disallowing the deduction of input VAT. The European Court of Justice and the European Court of Human Rights have dealt with liability and deduction cases. They have decided that closing the tax gap by recovering VAT from persons participating in the transactions is legal if it is done in accordance with the so-called knowledge test.
\end{abstract}

\section{Introduction}

Missing trader intra community (hereinafter: MTIC) Value Added Tax (hereinafter: VAT) frauds, also called carousel VAT frauds, are the largest ${ }^{1}$ form of the most serious EU VAT frauds. ${ }^{2}$ It is estimated that EU Member States lose EUR 100 billion per annum through this systematic tax fraud. ${ }^{3}$ Originally, ${ }^{4}$ MTIC VAT frauds were committed in specific in-

\footnotetext{
- Tax advisor and research assistant at the Graduate School of Government and European Studies (Fakulteta za državne in evropske študije), Kranj, Slovenia.

1 Daniel Kroesen and Walter de Wit, 'VAT Fraud in the Emissions and Energy Sector' (2011) Indirect Tax Briefing Issue 2, <http://www.ey.com/Publication/vwLUAssets/Indirect_Tax_in_2011/\$FILE/Indirect_Tax_2011.pdf> accessed 4 April 2012, 7.

2 Other forms of serious EU VAT frauds, which will not be discussed here, are: missing trader extra-community fraud in tradable services (MTEC); non-compliance by registered firms or sales suppression (a fraud of manipulating cash register records); and non-registration. For a detailed analysis of the first two, see Richard T Ainsworth, 'Zappers \& Phantom-Ware: A Global Demand for Tax Fraud Technology' (2008) Boston University School of Law Working Paper No 08-20 <http://www.bu.edu/law/faculty/scholarship/workingpapers/documents/AinsworthR060208.pdf> accessed 2 April 2012; Richard T Ainsworth, 'VAT Fraud: MTIC \& MTEC - The Tradable Services Problem' (2010) Boston University School of Law Working paper No 10-39 <http://www.bu.edu/law/faculty/scholarship/workingpapers/ documents/AinsworthR111210.pdf> accessed 31 March 2012.

3 Kroesen and de Wit (n 1) 7.

4 Supposedly the first version of MTIC fraud in the EU involved smuggling gold across the Luxembourg border, where the tax rate for gold was 0\%, selling this gold with VAT in an-
} 
dustries by transactions with high value / low weight goods such as mobile phones and computer microchips (mostly central processing units or CPUs) because they were easy and inexpensive to transport. Since then, frauds have shifted to the sales of other goods (new and used motor vehicles, wood, alcohol and tobacco products, oil and oil derivatives, gas and electricity, etc.) and even to the tradable services ${ }^{5}$ sector (software, licensing, data provision, emissions trading, etc) ${ }^{6}$ which, unlike goods, do not need to be moved, because they are immaterial.

MTIC occurs because of a fundamental flaw in the design of the EU VAT system. This type of fraud is not known in other (non-EU) tax systems which tax consumption. ${ }^{7}$ Businesses participating in such frauds abuse a fundamental flow in the design of the EU VAT system ${ }^{8}$ that has existed since 1 January 1993, when the internal market was established ${ }^{9}$ and when barriers to internal (intra-Community) trade were therefore abolished. Member States adopted a transitional system under which intra-Community business-to-business transactions are taxed in the Member State of destination, at the rate and under the conditions of that Member State. These transactions are basically taxed as if they were exports from one Member State and imports to another Member State. This means that sales are zero-rated and therefore no VAT is charged on purchases. This allows taxable persons to collect VAT from the purchasers on onward sales and then to disappear without remitting the collected tax. ${ }^{10}$ In comparison with real exports and imports, in intra-Commu-

other Member State, and then disappearing. At least for investment gold, a special scheme was adopted in the EU VAT system in 1993 to combat fraud in that market. Ainsworth, 'VAT Fraud: MTIC \& MTEC' (n 2) 29.

5 Most services are so-called consumed services, which are consumed on purchase. Auto repairs, construction, restaurant services are a few examples of these services. Because of their nature, they are consumed by the person these services are supplied to. Other kinds of services are so-called tradable services. They are designed from the beginning for re-sale. They are hybrid supplies that behave commercially like goods but have functional attributes that make them hard to distinguish from services generally. Ainsworth, 'VAT Fraud: MTIC \& MTEC (n 2) 1.

6 Kroesen and de Wit (n 1) 7.

7 But it should be noted that, in general, every VAT regime is susceptible to missing trader fraud, because in every VAT regime circumstances exist where business-to-business transactions are made without VAT being charged. This rule allows missing trader VAT fraud to take place. Richard T Ainsworth, 'VAT Fraud and Technological Solutions' (2011) The VAT Reader - What a Federal Consumption Tax Would Mean for America <http://www.taxanalysts.com/ www/freefiles.nsf/Files/VATReader.pdf/\$file/VATReader.pdf> accessed 22 April 2012, 204.

8 European Union Committee, Stopping the Carousel: Missing Trader Fraud in the EU (HL 2006-07, 101) para 2.

9 Peter Grilc and Tomaž Ilešič, Pravo Evropske unije, vol 1 (Cankarjeva založba 2001) 38-39.

10 Commission Staff Working Paper, 'On Measures to Change the VAT System to Fight Fraud' COM(2008)109 <http://ec.europa.eu/transparency/regdoc/rep/2/2008/EN/22008-249-EN-1-0.Pdf> accessed 3 May 2012, 8. 
nity transactions goods are not controlled physically at borders, but only through document control (VAT returns and recapitulative statements).

The second section of this article explains how MTIC and carousel VAT frauds are carried out. In order to understand the discussion that follows, we will begin with a simple explanation of the current VAT system, focusing on intra-Community trade and will continue by defining MTIC and carousel VAT frauds and measures to prevent them. In the third section, milestone cases in which the ECJ has dealt with MTIC or carousel VAT frauds are described. These decisions are frequently used, at least in Slovenia, in tax inspectors' decisions and in court judgements to elaborate reasons for them. As Croatia is to become the $28^{\text {th }}$ Member State on 1 July 2013 it will soon have to deal with the VAT fraud that is discussed in this article. Section four deals mostly with the leading VAT case where the European Court of Human Rights (ECtHR) decided that Article 1 of Protocol 1 to the European Convention on Human Rights (ECHR) had been violated. Section five analyses the ECJ and ECtHR case law and section six concludes the article.

\section{What are MTIC VAT frauds and carousel VAT frauds?}

In this section we will first explain the basics of the EU VAT regime. This will help us understand how MTIC and carousel frauds are performed. The last subsection deals with possible measures to fight MTIC and carousel VAT frauds.

\subsection{The transitional VAT regime for intra-Community supplies of goods}

VAT in EU is a general turnover tax, or, in other words, a general indirect tax on consumption of goods and services. It is an all-stage tax, which means that all stages of distribution and production are covered. The tax credit (invoice) method allows taxable persons to deduct VAT paid on purchases (input) from the tax due on sales (output). ${ }^{11}$

To put it simply, ${ }^{12}$ according to Article 2 RVD, four transactions are subject to VAT:

\footnotetext{
${ }_{11}$ Article 1 of the Recast VAT Directive (hereinafter: RVD), Council Directive 2006/112/EC of 28 November 1996 on the Common System of Value Added Tax [2006] OJ L 3471.

For a detailed theoretical explanation of different sorts of VAT, see Ben Terra and Julie Kajus, A Guide to the European VAT Directives, vol 1 (IBFD 2011) 271-314.

12 In should be noted that the listed transactions are only subject to VAT if other criteria are met. All, except importation, are only subject to VAT if they are made for consideration and by a taxable person acting as such (in general, a person who has a VAT identification number).
} 
- supplies of goods within the territory of a Member State;

- intra-Community acquisition of goods within the territory of a Member State in (simplified) business-to-business transactions; ${ }^{13}$

- supplies of services within a territory of a Member State; and

- importation of goods.

As mentioned above, a transitional ${ }^{14}$ VAT system for intra-Community transactions is currently in use. The transitional arrangement between Member States was supposed to be replaced by a definitive system for the taxation of trade between Member States based in principle on the taxation in the Member State of origin of the goods or services supplied. The date for replacement was set for 31 December 1996, but it was already arranged that the period of application of the transitional arrangements would be extended automatically until the date of entry into force of the definitive system and in any event until the Council decided on the definitive system. ${ }^{15}$ This transitional system is still valid today, ${ }^{16}$ which makes MTIC frauds possible.

Since business-to-business intra-Community acquisitions are considered as taxable transactions, such intra-Community supplies are VAT free. Actually, they are zero-rated, which means that the supplier is entitled to a VAT deduction or a refund of input VAT in the 'exporting' Member State. The intention of zero rates is to safeguard the principle of taxation in the country of destination. ${ }^{17}$ The intra-Community supplier can therefore deduct or claim a refund of the amount of his input VAT regarding the supplied goods in the country of origin. In the country of destination, the acquirer is obliged to self-account ${ }^{18}$ the amount of VAT on this transaction ${ }^{19}$

\footnotetext{
13 Exceptions for sales made by small entrepreneurs, distance selling, installation and assembling, as well as special regimes for intra-Community acquisitions of new means of transport and products subject to excise duties, will not be discussed here, as they are not vital for this article.

14 Article 402 RVD states that the transitional system will be replaced by definitive arrangements based in principle on the taxation in the Member State of origin of the supply.

15 Council Directive 91/680/EEC of 16 December 1991 supplementing the common system of value added tax and amending Directive $77 / 388 / \mathrm{EEC}$ with a view to the abolition of fiscal frontiers [1991] OJ L376/1.

16 Bojan Škof, Davek na dodano vrednost po novem - kako poslovati na notranjem trgu - 101 primer (Davčni inštitut, 2004) 15-16.

17 Terra and Kajus (n 11) 791.

18 Also called 'postponed accounting' or 'deferred payment'. We will later see that this makes MTIC VAT frauds possible.

19 Intra-Community supplies of goods between two taxable persons with valid VAT identification numbers are taxed in the Member State where dispatch or transport of these goods ends (Article 40 RVD) or in the Member State which issued the VAT identification number under which the person acquiring the goods made the acquisition (Article 41 RVD). Similar rules apply to (intra-Community) supply of services, including tradable services. According
} 
and can at the same time deduct this amount (Article 168(c) RVD). ${ }^{20}$ So, no amount of VAT is actually paid into the budget of the destination country when the acquisition takes place. In principle, the destination country collects VAT when the next transaction is performed - when the acquirer supplies the acquired goods to a third person in the same country.

\subsection{MTIC and carousel VAT frauds explained and measures to prevent them}

\subsubsection{Missing trader and MTIC frauds}

Generally speaking, a missing trader is a VAT taxable person that collects VAT on sales and then disappears, absconding with the VAT collected. ${ }^{21}$ The EU definition is, in my opinion, narrower. Commission Regulation (EC) 1925/2004 of 29 October 2004 laying down detailed rules for implementing certain provisions of Council Regulation (EC) 1798/2003 concerning administrative cooperation in the field of value-added tax [2004] OJ L331/13 defines in Article 2 (for the purposes of the regulation) 'missing trader' as a trader registered as a taxable person for VAT purposes who, potentially with a fraudulent intent, acquires or purports to acquire goods or services without payment of VAT and supplies these goods or services with VAT but does not remit the VAT due to the appropriate national authority. In comparison with the general meaning of missing trader, the EU definition clearly requires that the (factual or purported) acquisition of goods and services must be without the payment of VAT. The second part of the definition is similar - the trader goes missing without paying the collected VAT to the budget. Regardless of the definition, it is clear that to be considered a missing trader it is not necessary for the taxable person to be involved in intra-Community transactions.

In the following examples ${ }^{22}$ we will show that it is far more lucrative to be a missing trader in situations where goods and services are acquired without paying VAT.

to a general rule, business-to-business supplies of services are taxed where the taxable person to whom the services are provided has established his business (Article 44 RVD).

20 It must be noted that the acquirer can deduct the full amount only if he has the right to the full deduction. To put it simply, the acquirer can do so if the transactions he provides are not exempted from VAT.

21 In Slovenia's example, this usually means that the firm is transferred from real decision makers to indigent and uneducated individuals not residing in Slovenia but rather in the countries of ex-Yugoslavia, mostly Bosnia and Herzegovina and Serbia. Most of them have never been to Slovenia and do not plan to go there. These persons are formal directors and are owners of rather small amounts of money. The actual decision makers are Slovenian citizens who collect the illegal 'profits'.

22 The example is adapted from Leah Durner and Jon Sedon, 'VAT Administration Issues and Enforcement' (Views on VAT: An Article Series 2011) <http://www.kpmginstitutes. com/taxwatch/insights/2011/pdf/vat-compilation.pdf> accessed 4 May 2012, 70-71. 
Suppose companies A, B and C are all VAT registered taxable persons in Member State X that has a VAT rate of $20 \%$. They all operate exclusively in Member State X. Suppose Company A sells goods to Company B for EUR 120 (EUR 100 net price and EUR 20 VAT). Company B resells these goods to Company C for EUR 144 (EUR 120 net price and EUR 24 VAT). Company B then disappears without filing its periodic VAT return and remitting EUR 24 VAT collected from Company $\mathrm{C}$ to the budget of Member State X. Company B illegally 'earns' EUR 4 in VAT from the added value (EUR 24 not remitted minus EUR 20 paid to company A). ${ }^{23}$

Now, assume that Company A operates exclusively in Member State $\mathrm{X}$ while Companies $\mathrm{B}$ and $\mathrm{C}$ operate exclusively in Country $\mathrm{Y}$ which is not a Member State but has the same 20\% VAT rate. Exports from Member State X are zero-rated, but at the border to County Y, VAT is collected by customs from the importer (Company B), so the result stays as above. If Company B disappears without filing its periodic VAT return and remitting the VAT collected from the sale of goods to Company C, it will illegally 'earn' EUR 4 (added value is EUR 20 plus 20\% of this amount). ${ }^{24}$

In intra-Community transactions, however, where Company A operates exclusively in Member State $\mathrm{X}$ and Companies $\mathrm{B}$ and $\mathrm{C}$ operate exclusively in Member State $Z$ (where the VAT rate is 20\%), the missing trader gain can be greater. The fiscal frontiers between EU Member States are abolished and customs no longer allot VAT. Instead, VAT is self-accounted by the acquiring business (Company B). Company A will issue an invoice without VAT (net invoice, stating that Company B has to pay EUR 100). After the intra-Community acquisition, Company B sells the goods to Company C and collects EUR 144 (EUR 120 is the net price and EUR 24 is VAT). Then it disappears without filing its periodic return ${ }^{25}$ in which it would have to self-declare the acquisition from Company A (EUR 20 VAT), the right to deduct this amount and the supply of goods to Company $\mathrm{C}$ (EUR 24 VAT). This means that Company B will illegally 'earn' EUR 24. The same amount is the revenue loss of Member State $Z$.

The last example above shows the MTIC modus operandi.

\footnotetext{
${ }_{23}$ It must be noted that the gain for the missing trader could be EUR 24 if the taxable person (in his periodic VAT return) claims for an (actual or calculative) refund of the input VAT (EUR 20) that he paid to the supplier. This claim would be very bold, since the chances for the tax authorities to catch the missing trader would be greater. But it is still possible.

24 Under the same criteria as in the previous footnote, the gain for the missing trader could also be EUR 24.

25 Other options are (1) that periodic returns are filed, but the mentioned transactions are not reported, or (2) that periodic returns are filed and the mentioned transactions are reported but are not paid. Marjan Maček, 'Sistemske utaje davka na dodano vrednost in ugotovite davčne uprave RS' (2010) 1 Pravosodni bilten 117, 123.
} 


\subsubsection{Carousel frauds}

Carousel frauds are a more complex variation of MTIC frauds. A group of companies sell the same goods or services in a circle to achieve an illegal 'profit' by repeating the MTIC modus operandi over and over again. The main difference between MTIC and carousel frauds is therefore that goods or tradable services eventually make their way back to the original seller, completing the loop (thus the term 'carousel'). ${ }^{26}$ One of the basic models is drawn below. Note that this is a simplified model and that many variations are possible in practice. They include transactions between ten and more participants and several Member States, which makes detection and proving the connections very difficult, if not impossible. ${ }^{27}$

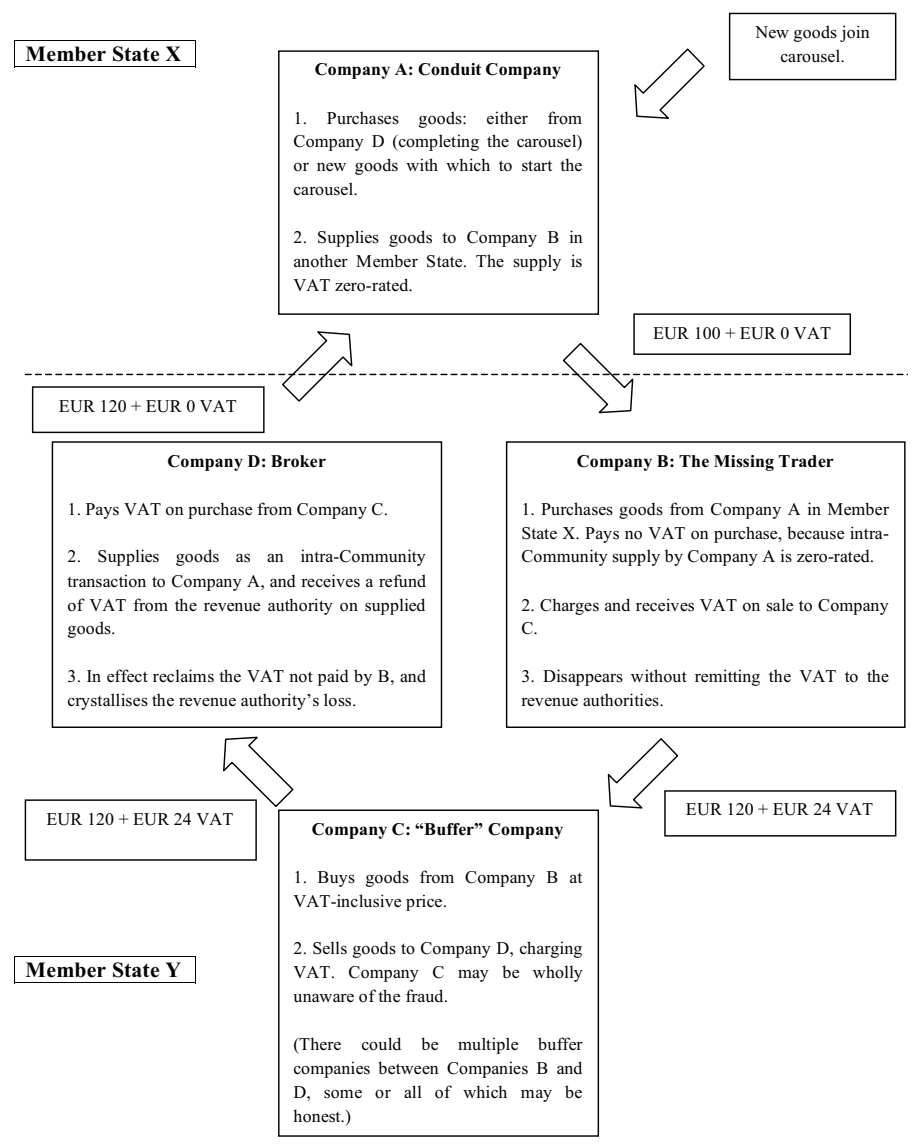

Figure 1: A basic carousel fraud model ${ }^{28}$

\footnotetext{
26 Durner and Sedon (n 22) 71.

27 Stephen Smith, 'VAT Fraud in the European Union' (VAT: Current Issues of Interest Workshop 2008) PE Report 400.993 11, 13.

28 Adapted from European Union Committee (n 8) para 6.
} 
For the sake of simplicity, let us assume that Member States X and $\mathrm{Y}$ have a 20\% VAT rate. Company A from Member State X sold goods for EUR 100 to Company B located in Member State Y. Company A (missing trader company) performs an intra-Community supply which is zero-rated and therefore charges no VAT to Company B. Company B has to selfaccount the VAT (EUR 20) on its next periodic return because it made an intra-Community acquisition (so-called reverse charge mechanism). Company B then sells goods to Company C (buffer company) in the same Member State for EUR 144 (EUR 120 net price and EUR 24 VAT). Company $\mathrm{B}$ does not report the acquisition, does not deduct input VAT and also does not report the supply to Company $\mathrm{C}$ and therefore gains an illegal EUR 24 of VAT that should be paid into Member State Y's budget. Company $\mathrm{C}$ then sells the goods to Company D for the same price. Since no value was added, the input and output tax are the same amount, and no additional VAT is remitted to Member State Y. Company D then performs an intra-Community supply to Company A in Member State X. This supply is zero-rated, but Company D collects input VAT from Member State $\mathrm{Y}$ that it paid when purchasing the goods from Company C (EUR 24). Company A can then start the carousel again using the same companies and Member States, or different ones. ${ }^{29}$

It should be noted that the conduit company (Company A), the missing trader (Company B) and the broker (Company D) are the ones that planned the fraud. ${ }^{30}$ The main purpose of the Buffer Company is to conceal the link between the missing trader (Company B) and the broker (Company D). ${ }^{31}$ Company $\mathrm{C}$ can participate in the fraud either knowingly or unknowingly.

\subsubsection{How to prevent MTIC and carousel VAT frauds}

Theoretically, there are several ways to prevent or minimise MTIC and carousel VAT frauds. For the purposes of this article, we will divide measures into two groups: in the first one there are those that do not

\footnotetext{
29 In one of the widely reported carousel fraud cases, a 21-year-old fraudster appeared to be selling $10 \%$ of the world supply of a kind of computer chip. In fact, he had only a single box of chips going round and round in UK-Irish cross-border trade. Richard T Ainsworth, 'VAT Fraud and Technological Solutions' (n 7) 204, 205.

30 These kinds of frauds are commonly performed by gangs involved in (more or less) organised crime. They can either be involved in just this sort of criminal activity alone, or MTIC and carousel frauds can form part of their activities, such as money-laundering and smuggling. European Union Committee (n 8) para 31. Similarly Konstantin Pashev, 'Fighting VAT Fraud: The Bulgarian Experience' (2006) Center for the Study of Democracy Working Paper 0606/2 <http://eduart0.tripod.com/sitebuildercontent/sitebuilderfiles/vatfraudbulgaria_ 21f.pdf $>$ accessed 6 May 2012.

31 Maček (n 23) 117, 122.
} 
demand any changes of the current intra-Community VAT system and can therefore be implemented by each Member State individually; the second group consists of either implementing technological solutions (for example, Real Time VAT, the VAT Locator Number, Digital VAT) ${ }^{32}$ or abolishing the zero-rating of intra-Community business-to-business trade. ${ }^{33}$ We will deal only with the first group here.

The first possibility is the least radical. It consists of improving:

- the performance of tax inspections;

- cooperation between tax authorities in different Member States;

- imposing liability on persons participating in frauds and refusal of VAT deduction, etc. ${ }^{34}$

The goal here is to prevent MTIC and carousel frauds without changing the current taxation of intra-Community supplies (zero-rate, reverse charge, deferred payment). Organisational measures can be implemented, such as establishing special departments that deal exclusively with detecting and investigating MTIC and carousel frauds, training of tax inspectors, etc. Other measures could include tighter checks on businesses seeking to register for VAT (on-sight visits, review of concluded contracts, examination of business plans, etc), ex officio withdrawal of VAT identification numbers, slowing down payments of VAT refunds relative to the collection of the VAT due, requiring guarantees in dubious cases, the obligation for new VAT identified taxable persons to file returns every month for a period of one year, regardless of their turnover, introducing reverse charges in risky sectors (construction, real estate supplies, waste supplies, etc) for supplies in a Member State, ${ }^{35}$ introducing transfer pricing to determine taxable amounts in the case of transactions between closely connected (associated) taxable persons, the obligation for taxable persons that file their first VAT return to enclose a list of received and issued invoices, etc. ${ }^{36}$ Member States should more often use the possibility

32 For a more detailed explanation, see Ainsworth, 'VAT Fraud and Technological Solutions' (n 7) 204, 210-23.

33 For more on alternatives to zero-rating in intra-Community trade, see Smith (n 25) 11 , 17-18 and European Union Committee (n 8) paras 53-76.

34 Improving misdemeanour and criminal proceedings could also be part of this category due to the special and general preventive function of misdemeanour and criminal law. But since we are focusing on mostly administrative measures in this article, these views will not be discussed here.

35 The effect of introducing a reverse charge on certain products has had limited success, because the fraudsters can simply move to other goods. On the other hand, a universal reverse charge is not the answer, because VAT would become a single-stage retail tax and therefore more susceptible to revenue loss through unreported sales.

36 Some of these measures were introduced by the Slovenian tax authority to prevent MTIC and carousel VAT frauds. Maček (n 23) 124-30. 
to exchange relevant data and use the VAT Information Exchange System (hereinafter VIES), operated by the European Commission. ${ }^{37}$ Since it is often impossible to claim stolen VAT from missing traders, tax authorities can demand the same amount from other businesses that have collaborated in the frauds by refusing VAT deductions or by imposing their liability to pay for the missing amount of VAT. We will discuss these issues in the next section, where the ECJ case law is described.

Finally, it must be noted that these measures only prevent MTIC and carousel frauds to some extent, but they cannot prevent them entirely. Furthermore, they also impose on-going costs on businesses. A permanent solution would therefore be either to implement one of the technological solutions or to change the taxing of intra-Community businessto-business trade. Due to a lack of political will in Member States, this is easier said than done. All Member States must unanimously agree with changes to the system. Basically, they all agree that the system must change, but cannot agree on how.

\section{ECJ case law}

Since Member States cannot unanimously agree on which technological solutions should be implemented or even on how intra-Community supplies should be taxed in order to prevent MTIC and carousel frauds, it is up to each Member States to do its best to minimise the MTIC and carousel fraud VAT gap. ${ }^{38}$

Since missing trader firms are missing, 'stolen' VAT cannot be accessed from them, so Member States try to retrieve at least some of these amounts from persons who were knowingly or unknowingly part of the MITC or carousel tax fraud chain. Conditions under which they can do this are best presented in the ECJ milestone judgments that deal with MTIC and carousel frauds. They basically deal with two issues: (1) to

Smith (n 25) 11, 15-17 notes: 'But it has to be noted that these measures may reduce the risk of VAT fraud, some of them may have less-desirable side-effects. More bureaucratic VAT registration procedures and slower payment of VAT refunds might harm legitimate business as well as discouraging fraud, and these effects may outweigh the enforcement gains. The authorities have a difficult balance to strike, between ensuring that VAT administration does not impose excessive burdens on business in general and ensuring that it is not unduly exposed to fraud. Some level of VAT evasion may well have to be tolerated in the wider business interest.'

37 According to the European Union Committee (n 8) para 34, in 2005 VIES was significantly underused. Due to the lack of current data, we cannot say if this has statistically improved throughout the Community, but in our experiences representing clients in tax law cases Slovenian tax authorities are constantly monitoring the VIES system, searching for possible VAT frauds.

38 The VAT gap is the difference between net VAT liability and total VAT collections. 
refuse a VAT deduction for supplies made to a business by a missing trader, and (2) to hold a business jointly and severally liable for participating in an MTIC or carousel fraud.

\subsection{Refusal of a VAT deduction}

There are two milestone cases in which the ECJ developed its standpoint on VAT deduction when a missing trader made a supply to a taxable person and made a deduction on the basis of a received invoice: joint cases Optigen Ltd, Fulcrum Electronics Ltd and Bond House Systems Ltd $v$ Commissioners of Customs \& Excise ${ }^{39}$ (hereinafter Optigen and others) and joined cases Axel Kittel $v$ État belge and État belge $v$ Recolta Recycling $S P R L^{40}$ (hereinafter Kittel and Recolta).

\subsubsection{Optigen and others}

Optigen, Fulcrum and Bond House essentially carried out the business of buying central processing units (CPUs) from companies established in the United Kingdom and selling them to purchasers established in another Member State. The transactions in question formed part of a carousel, but Optigen, Fulcrum and Bond House were not aware of this. The question that the ECJ had to answer was, first, if transactions which are not themselves vitiated by VAT fraud, but which form part of a chain of supply in which another prior or subsequent transaction is vitiated by such fraud, without the trader engaged in the first transactions knowing or having any means of knowing, constitute supplies of goods or services effected by a taxable person acting as such and an economic activity, and, second, whether, in such circumstances, the right of that trader to deduct input VAT may be limited.

In paragraphs 53 and 54, the ECJ repeated its view on the right to deduct. This right is an integral part of the VAT scheme and in principle may not be limited. It must be exercised immediately in respect of all the taxes charged on transactions relating to inputs. It is therefore irrelevant for the right to deduct input VAT whether the VAT on the earlier or later sale of the goods concerned to the end-user has or has not been paid to the public purse.

In the ECJ's view (paragraph 55), a taxable person cannot be denied the right to deduct input VAT only because he was, without knowing or having any means of knowing, participating in a carousel fraud. It is

\footnotetext{
39 Joint cases C-354/03, C-355/03 and C-484/03 Optigen Ltd, Fulcrum Electronics Ltd and Bond House Systems Ltd v Commissioners of Customs \& Excise [2006] ECR I-483.

40 Joint cases C-439/04 and C-440/04 Axel Kittel $v$ État belge and État belge $v$ Recolta Recycling SPRL [2006] ECR I-06161.
} 
clear that the ECJ has indicated, but not expressly stated, that a taxable person that was knowingly participating in carousel frauds would not have the right to deduct input VAT. ${ }^{41}$

\subsubsection{Kittel and Recolta}

Ang Computime Belgium ('Computime') bought and resold computer components. The Belgium tax authorities decided that Computime had knowingly participated in a carousel fraud and that the supplies effected to Computime were fictitious. As a result, they refused to allow Computime the right to deduct the VAT paid on those supplies (Mr Kittel was Computime's receiver).

Recolta bought luxury vehicles. The relevant seller did not account for the VAT paid by Recolta, which resold the vehicles free of VAT (intraCommunity supply). An investigation showed that both parties selling to Recolta and purchasing from it had set up a carousel fraud, of which the transactions with Recolta formed part. Recolta was issued with a demand for payment.

The ECJ was asked two questions. To put it simply, the first question was whether the doctrine of Optigen and others is also valid in transactions where the supplier commits a fraud in relation to the recipient - a taxable person - who did not know and could not have known anything about the fraud. The second question was whether a taxable person who is a recipient of the supply of goods who knew or should have known that he was participating in a transaction involving the fraudulent evasion of VAT loses his right to deduct input VAT connected with those transactions.

So the Kittel and Recolta case is actually an evolution of the case of Optigen and others. The ECJ states that the doctrine of Optigen and others is also applicable to fraudulent transactions where the recipient of the supplies knows nothing or could know nothing (paragraph 46). So, if a supplier is fraudulent, but the recipient knows nothing or could not know of his intention, the recipient's right to deduct input VAT, connected with that transaction, stays intact. For the right of the taxable person to deduct input VAT, it is also irrelevant if VAT was actually paid to the Treasury (paragraph 48).

Taxable persons who take every precaution which could reasonably be required of them to ensure that their transactions are not connected with a fraud must be able to rely on the legality of those transactions

${ }_{41}$ The ECJ dealt with this question less than six months later in the Kittel and Recolta case. 
without the risk of losing their right to deduct input VAT (paragraph 51). A taxable person who knew or should have known that through his purchase he was taking part in transactions connected with the fraudulent evasion of VAT must be regarded as a participant in the fraud, irrespective of whether or not he profited through the resale of the goods. In such situations, the taxable person aids the perpetrators of the fraud and becomes their accomplice (paragraphs 56 and 57).

The ECJ notes that such an interpretation of the VAT system makes it more difficult to carry out fraudulent transactions and is apt to prevent them.

\subsection{Joint and several liability}

The main case in which the ECJ dealt with joint and several liability is Case C-384/04 Commissioners of Customs \& Excise, Attorney General $v$ Federation of Technological Industries and Others [2006] ECR I-4191 (hereinafter: FTI and others).

The facts of the case were that a large group of companies was trading in mobile telephones and computer processing units. They were collaborating in MTIC and carousel frauds. According to the VAT Act valid in the United Kingdom, the tax commissioner decided that they were jointly and severally liable for unpaid VAT by missing traders. In the proceedings before the ECJ, they claimed that the provision of VAT Act, on the basis of which they were ordered to pay VAT, was contrary to Community law.

The ECJ disagreed with their view, but defined a few limits. Member States are allowed to enact legislation which provides that a taxable person, to whom a supply of goods or services has been made and who knew, or had reasonable grounds to suspect, that some or all of the value added tax payable in respect of that supply, or of any previous or subsequent supply, would go unpaid, may be made jointly and severally liable, with the person who is initially liable, for payment of that tax. But such legislation must comply with the general principles of law which form part of the Community legal order and which include, in particular, the principles of legal certainty and proportionality. In addition, Member States may enact measures which impose on the jointly and severally liable persons a requirement to provide security for the payment of that tax which is due.

So those traders who take every precaution which could reasonably be required of them to ensure that their transactions do not form part of a chain which includes a transaction vitiated by VAT fraud must be able to rely on the legality of those transactions without the risk of being 
made jointly and severally liable to pay the VAT due from another taxable person.

So Article 205 RVD allows Member States to pass a law according to which taxable persons who knew, or had reasonable grounds to suspect, that they are part of an MTIC or carousel fraud can be held liable to pay 'stolen' VAT.

\section{ECtHR case law}

The leading ECtHR case that deals with responsibility in VAT frauds is the Bulves $A D$ case. ${ }^{42}$ Bulves $\mathrm{AD}$, a Bulgarian joint-stock company, was a VAT taxable person that purchased goods from another taxable person, paid the amount on the invoice and deducted the input VAT. Upon audit, the tax inspector decided that Bulves $\mathrm{AD}$ was not entitled to the credit, as the supplier had failed to record its supply of goods in its accounting records for the month that the supply was made (August 2000), but did so in October 2000.

The ECtHR decided that Bulgaria violated Article 1 of Protocol No 1 to the ECHR that provides for the right to the peaceful enjoyment of one's possessions, ${ }^{43}$ because VAT credit was disallowed. The reason for this decision was that Bulves AD had no knowledge of the potential fraud of the VAT system. Even more, the applicant had no means to obtain such knowledge. Therefore, Bulves AD should not suffer the full consequences of its supplier's failure to duly report the supply.

According to the ECtHR, Contracting States are allowed to curb fraudulent abuse of the VAT system of taxation. When Contracting States possess information of such abuse by a specific individual or entity, they may take appropriate measures to prevent, stop or punish it. However, it is considered that if national authorities, without any indication of direct involvement by an individual or entity in fraudulent abuse of a VAT chain of supply, ${ }^{44}$ or knowledge thereof, nevertheless penalise the fully compliant recipient of a VAT-taxable supply for the actions or inactions of a supplier over which it has no control and in relation to which it has

\footnotetext{
42 Bulves AD v Bulgaria App no 3991/03 (ECtHR, 22. January 2009).

43 Article 1, Protocol No. 1 to the ECHR

'Every natural or legal person is entitled to the peaceful enjoyment of his possessions. No one shall be deprived of his possessions except in the public interest and subject to the conditions provided for by law and by the general principles of international law.

The preceding provisions shall not, however, in any way impair the right of a State to enforce such laws as it deems necessary to control the use of property in accordance with the general interest or to secure the payment of taxes or other contributions or penalties.'

44 The ECtHR repeated its view in the case Intersplav $v$ Ukraine App no 803/02 (ECtHR 25 May 2007) para 38.
} 
no means of monitoring or securing compliance, they are going beyond what is reasonable, and upset the fair balance that must be maintained between the demands of the general interest of the community and the requirements of the protection of the right of property.

Interestingly, in the Bulves case, the ECtHR briefly analysed the ECJ case law discussed above..$^{45}$ But since Bulgaria had only entered the EU on 1 January 2007, Bulves AD could only seek protection before the ECtHR and not before the ECJ.

The ECtHR repeated its views in yet another Bulgarian case, namely the Business Support Centre ${ }^{46}$ case. The facts of this case are basically the same as those in the Bulves case and will not be discussed here. Simply put, the Court decided that if there are no assertions that there was fraud in relation to the VAT system of which a taxable person who deducts input VAT had any knowledge or the means to obtain such knowledge, that person cannot be denied VAT deduction (paragraph 24). The Court also added that when tax authorities discover that a supplier has failed to fully and timely discharge his VAT reporting and payments obligation, they must take the initiative to collect VAT from the supplier and not to deny the acquirer the right to deduct input VAT.

\section{A short ECJ and ECtHR case law analysis}

The ECJ's view is based on the so-called knowledge test. A taxable person with factual or implied knowledge that he was participating in fraud is either not allowed to deduct input VAT or can be jointly and severally liable for the payment of the 'stolen' amount of VAT to the budget. Free from liability are those taxable persons who take every precaution which can reasonably be required of them to ensure that their transactions do not form part of a chain of fraud.

The ECtHR is, in my opinion, basically saying the same but using a slightly different wording. ${ }^{47} \mathrm{~A}$ taxable person is allowed to deduct input VAT if he had no knowledge (factual knowledge) or had no means to obtain such knowledge by means of the ability to control the person

\footnotetext{
45 FTI and others; and Kittel and Recolta (paras 29-32).

46 Business Support Centre v Bulgaria App no 6689/03 (ECtHR 18 June 2010).

47 For a different opinion, see Vladimir Gritsenko, 'A Taxing Question for Human Rights: The European Court of Human Rights, the Value Added Tax, and the Russian Federation' (2011) SMC LTD, <http://papers.ssrn.com/sol3/papers.cfm?abstract_id=1786993\#captch aSection> accessed 13 May 2012, 5 .

The author states that a Plenum of the High Arbitration Court of the Russian Federation in 2006 issued guidelines that are consistent with ECtHR case law.
} 
who evaded VAT, by means of the ability to monitor and secure his VAT compliance (implied knowledge).

In short, taxable persons must be careful and prudent in their business transactions in which VAT should paid. They must take every reasonable precaution to avoid transactions involving VAT fraud, and if they act in such a way, they cannot be held liable for the payment of VAT or denied the right to deduct input VAT. The same rules apply in the EU and the ECHR Member States.

\section{Conclusion}

The main reason for MTIC and carousel frauds is the transitional VAT system for taxing intra-Community supplies with its zero-rating in the 'exporting' Member State. It is expected that Member States will not be able to agree on a different definitive system soon and this transition will last for several years. This means that the opportunity for MTIC and carousel frauds will not be eliminated. In the meantime, Member States will continue to minimise the tax gap arising from these systematic VAT frauds by imposing liability on other persons participating in the VAT frauds, either by not allowing them to deduct input VAT or by imposing their joint and several liability for the 'missing' VAT. Under the current ECJ and ECtHR case law, which is not likely to change, 'stolen' VAT can only be recovered from them if they knew or should have known that they are participating in VAT fraud. As long as these persons are careful enough to ensure that their transactions are not part of the fraud, no VAT will be imposed on them.

This solution is not adequate to prevent MTIC and carousel frauds. I see it more as a limitation on tax inspectors, so that they are constrained to impose missing VAT on innocent taxable persons who are part of the chain transaction. Sooner or later, a more permanent solution will have to be enacted. The size of the MTIC and carousel frauds is just too big and Member States are losing too much. The financial crisis has already lowered Member States income from VAT and this could be a good time to rethink the taxation of intra-Community supplies. 